\title{
Evidence of Quarrying at the Iron Age Site of Torre d'en Galmés, Menorca, Spain
}

\author{
A. Pérez-Juez ${ }^{(1,2 \text { y } 4)}$ y P. Goldberg ${ }^{(2 \times 3)}$ \\ (1) Boston University-Madrid, Miguel Angel 8, E-28010 Madrid, Spain \\ amaliapj@bu.edu \\ (2) Department of Archaeology, Boston University, 675 Commonwealth Ave., Boston, MA, USA
}

(3) Institute for Archaeological Sciences, University of Tübingen, Rümelinstr 23, D-72070 Tübingen, Germany paulberg@bu.edu

(4) CAS, SEES, University of Wollongong, Northfields Ave., Wollongong, NSW 2522 Australia

(5) IME, Institut Menorquí d'Estudis

\begin{abstract}
The island of Menorca (Balearic Islands, Spain) contains numerous megalithic structures (e.g., watchtowers, sanctuaries) and private buildings (e.g., domestic spaces, storage areas). Until recently, archaeological research has concentrated on architecture (and associated material remains), but research on the raw materials (source, method of quarrying and their social implications) in constructing these monuments has been very sparse. This paper summarizes some initial results of our recent excavations at Torre d'en Galmés, which show that the quarrying of limestone was widespread: within buildings, in open spaces between buildings, and beyond the limits of the main occupation of the site. Inhabitants exploited joints and bedding planes in the Miocene limestone that covers the southern half of the island, ignoring softer marls, which have been quarried for construction only since the Roman conquest. The sizes and shapes of the quarried blocks can be used to reflect on social aspects, since quarrying of small blocks within buildings could have been whereas the extraction, transport, and construction of large standing uprights from outside the limits of the site would have required a greater communal effort.
\end{abstract}

Key words: Iron Age, limestone, Menorca, Miocene, quarrying, Talayotic.

\section{Evidencia de extracción de piedra en el yacimiento de la Edad del Hierro de Torre d'en Galmés, Menorca, España}

\author{
RESUMEN
}

La cultura talayótica se desarrolló en la isla de Menorca en el primer milenio a.C. En ese momento, el paisaje se transformó con la construcción de enormes estructuras megalíticas tanto públicas como privadas: talayots, taulas, salas hipóstilas, espacios domésticos, etc. (Figs. 1 y 2). Estas monumentales edificaciones han sido estudiadas en los últimos años por diferentes equipos de investigación. Sin embargo, aunque todas ellas están construidas con el mismo tipo de piedra caliza, se ha prestado todavía poca atención al aprovisionamiento y obtención de materias primas, a la localización de canteras y al estudio de los espacios entre estructuras. En este artículo se presentan los resultados preliminares de nuestra excavación en el yacimiento de Torre d'en Galmés, Menorca, que ponen de manifiesto la relación entre espacios intraurbanos y aprovisionamiento de materias primas para la construcción de edificios talayóticos.

Palabras clave: caliza, cantera, Edad del Hierro, extracción de piedra, Menorca, Talayótico.

\section{VERSIÓN ABREVIADA EN CASTELLANO}

\section{El yacimiento talayótico de Torre d'en Galmés}

La cultura talayótica debe su nombre a la palabra "talayot," proveniente del árabe "atalaya" (Figs. 2 y 3). Estas construcciones y la aparición de grandes asentamientos urbanos marcan el comienzo de la Edad de Hierro en Menorca. Los nuevos núcleos urbanos siguieron un mismo patrón constructivo, con edificios públicos como recintos de taula o talayots y complejos domésticos, áreas de almacenamiento, cisternas, etc. (Pérez- 
Juez, 2011; Pérez-Juez, 2013; Rosselló Bordoy, 1986; Sintes and Isbert, 2009). A partir del siglo V a. C., la presión comercial cartaginesa se observa en el aumento de ánforas púnicas y otros materiales importados. Pero la técnica constructiva se mantiene igual en lo que se ha denominado el periodo post-talayótico. La destrucción de Cartago en el año 146 a. C. y la conquista romana de las Baleares en el 123 a. C. suponen también el fin de las cuturas talayóticas y post-talayóticas.

Torre d'en Galmés es el yacimiento más extenso de Menorca y está situado a 125 m.s.n.m., en la parte sur de la isla (Migjorn) (Fig. 1c). La roca madre consiste en caliza articulada con laminación cruzada y bien cimen-

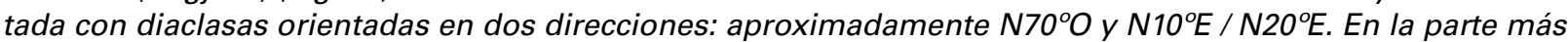
alta se encuentran los edificios de carácter público, taula y talayots (Fig. 3a). El resto de las estructuras se construyeron en la suave pendiente hacia el sur, sobre superficies aterrazadas que presentan un paisaje escalonado (Fig. 3b).

\section{Evidencias de extracción de piedra dentro del yacimiento}

En algunos yacimientos se ha intentado localizar las canteras pero solo en las zonas inmediatas al mismo (García-Amengual, 2012; Kopper and Rosselló-Bordoy, 1974; Serra, 1963). Sin embargo, el aprovisionamiento de materias primas para la construcción se realizó también dentro de los yacimientos como se evidencia en Torre d'en Galmés.

Evidencia dentro de los edificios

En el interior de todas las construcciones se observa tanto la extracción de bloques como la nivelación de la roca madre del suelo de ocupación (Figs. 3 y 5). En la Casa 2 (Fig. 5a) se explotó la roca madre siguiendo el sistema de diaclasas E-O/N-S (Figs. $5 a$ y $5 \mathrm{~b}$ ). La caliza arrecifal articulada y la estratificación entrecruzada permiten la fácil extracción de bloques. De esta manera, se dejó sin extraer en aquellos sitios en donde no existía este sistema de diaclasas y la roca aparecía demasiado masiva, lo que ha dado lugar a superficies irregulares en algunas zonas de la casa (Figs. 5b, 5c, 5e y 5f). Los negativos dejados por la talla y las cuencas de disolución naturales se rellenaron de forma antrópica con trozos de cerámica, huesos y carbón, con el fin de obtener un suelo uniforme (Fig. 5g) (Pérez-Juez et al., 2011). Este proceso se observa en otros yacimientos, como es el caso de Torralba d'en Salord (Fig. 6).

\section{Evidencia en espacios abiertos}

En zonas cercanas a la Casa 2 existen varios espacios abiertos usados como cantera, como se ha constatado en las terrazas al Norte y Oeste de la misma (Fig. 3b). A lo largo de los caminos actuales se observa también roca madre sin extraer así como los negativos de la extracción de materias primas (Figs. 7a y 7b).

Durante las campañas de excavación de 2012 a 2014, el equipo de Boston University excavó una cata denominada Trinchera $B(9 \times 1,5 \mathrm{~m})$ en una de las terrazas al noroeste de la Casa 2 con el objetivo de entender mejor el uso de estos espacios abiertos y aterrazados (Fig. 3b.2). La excavación puso de manifiesto la existencia de restos de roca madre aislados, rodeados de una matriz formada por diferentes materiales. Al final de la segunda campaña resultó evidente que esta microtopografía evidenciaba un espacio tallado, utilizado para la extracción de materiales de construcción. Los agujeros dejados habían sido rellenados inmediatamente después a la extracción de los bloques con una serie de depósitos calcáreos que contenían lascas, huesos, cerámica y lo que parecía, en principio, cenizas. Se tomaron muestras para un estudio micromorfológico de estos depósitos cenicientos y se realizaron láminas delgadas (Courty et al., 1989, Goldberg and Macphail, 2006) que revelaron muy pocos restos de ceniza. Sin embargo, se observó la existencia de una matriz rica en arena y limo calcáreo derivada de la talla de la caliza, que puede confundirse, a simple vista, con restos de cenizas (Fig. 9). La datación de radiocarbono sobre un hueso de estos depósitos cenicientos dio un resultado de $2540 \pm 30$ a BP (BETA \#356718) (Fig. 8).

\section{Discusión}

Los resultados anteriores revelan la enorme actividad de extracción de piedra realizada en el yacimiento de Torre d'en Galmés. Esto tuvo una serie de repercusiones tanto en el paisaje como en el urbanismo del yacimiento que se enuncian a continuación. 
Pérez-Juez, A. y Goldberg, P., 2018. Evidence of Quarrying at the Iron Age Site of Torre... Boletín Geológico y Minero, 129 (1/2): $353-370$

Materias primas

Aunque existen diferentes tipos de rocas en la isla, las estructuras talayóticas están construidas con el mismo material: calizas duras provenientes del talud arrecifal del Mioceno obtenida de todos los lugares posibles, tanto dentro del yacimiento como fuera de él (Fig. 10). La caliza blanda de las facies lagunares del Mioceno (marés) no fue utilizada hasta la llegada de los romanos.

Cambios en el paisaje por la extracción de piedra

Todas las edificaciones talayóticas siguen el mismo patrón constructivo: se limpiaba completamente la terra rossa del suelo, utilizando el mismo como cantera y extrayendo los bloques de piedra explotando las diaclasas naturales de la roca madre (Pérez-Juez, 2011). Los bloques extraídos se utilizaban para los muros exteriores que, una vez colocados, se tallaban lo que producía lascas que se acumulaban en el suelo de los edificios. Los negativos de la extracción de piedras y las cuencas de disolución de las calizas se rellenaban para nivelar el suelo. Los bloques más grandes se traían de las inmediaciones de los yacimientos, siguiendo el mismo proceso. La terra rossa desplazada en este proceso pudo haber producido una desestabilización del suelo natural, aumentando la erosión del mismo.

\section{Urbanismo de los yacimientos talayóticos}

El tipo de urbanismo de los yacimientos talayóticos y la relación entre zonas construidas y sin construir estuvo condicionado por la extracción de piedra. Las áreas abiertas entre los edificios se rellenaron de inmediato o se dejaron expuestas para su uso como cisternas o zonas de almacenamiento. En cualquier caso, los espacios abiertos estudiados hasta el momento reflejan seguramente un uso público o de circulación entre diferentes áreas del yacimiento (Fig. 3). Las superficies aterrazadas de esta parte sur de la isla se produjeron como consecuencia de la erosión de la roca durante el Mioceno, lo que dio lugar a un paisaje idóneo para la obtención de materias primas, definiendo el urbanismo general del yacimiento.

\section{Métodos de extracción de la piedra}

La técnica de extracción de piedra es todavía desconocida. En 1974, Kopper y Rosselló-Bordoy sugirieron que las canteras de Son Catlar podrían haberse explotado usando fuego (Kopper and Rosselló-Bordoy, 1974). Esto no fue así en el caso de Torre d'en Galmés, donde no existe ninguna evidencia de fuego en las zonas de cantera analizadas. El análisis micromorfológico demuestra una existencia muy limitada de cenizas mezclada con los depósitos de relleno tras la extracción de la piedra. Sin embargo, durante el proceso de excavación, es posible interpretar este relleno como formado únicamente por ceniza debido a su similitud en color y textura.

En cuanto a la tecnología utilizada, aunque se observan marcas en la roca madre y se han recuperado una cantidad muy alta de lascas provenientes de los retoques de la piedra, no se ha localizado ninguna herramienta. Seguramente se usó una técnica similar a la propuesta para la explotación de la mina de cobre de Sa Mitja Lluna en la Isla d'en Colom, Menorca (Hunt et al., 2013), con el uso de cuñas de madera, cinceles de hierro y otras herramientas de piedra.

\section{Conclusiones}

Las estructuras megalíticas de Torre d'en Galmés dominan el paisaje circundante. El asentamiento fue ocupado durante más de 2000 años, pero siempre siguiendo su urbanismo original. Lo que es excepcional en Torre d'en Galmés es el grado de conservación de las estructuras y la posibilidad de identificar todas las técnicas de extracción de material realizada en el mismo: desde pequeños sillares a enormes bloques de caliza. Las diaclasas del substrato influyeron en la arquitectura talayótica y ésta a su vez, en el urbanismo del sitio que refleja el modelado de la roca madre explotada. Todo esto debió tener consecuencias en la organización social de las comunidades talayóticas. La extracción, transporte y colocación de grandes pilares y bloques revela la complejidad de las sociedades talayóticas, tema ya estudiado en otras islas del Mediterráneo (Bonanno et al., 1990; Kolb, 2005; Renfrew et al., 1974). Un estudio sistemático de este proceso revelaría importantes datos sobre las comunidades que vivieron en Menorca en el primer milenio a.C. 


\section{Introduction}

The island of Menorca, Spain, hosted the development of the Talayotic Culture in the first millennium BC. During this period, the landscape was transformed by the construction of megalithic structures, both for public buildings -watchtowers and sanctuar- ies- as well as private buildings -domestic spaces and storage areas (Figs. 1 and 2). These striking features have been extensively studied in recent decades, and major archaeological projects have dealt primarily with the chronology, architecture, and objects found within the buildings (Gornés et al., 2001; Guerrero et al., 2002; Hernández-Gasch
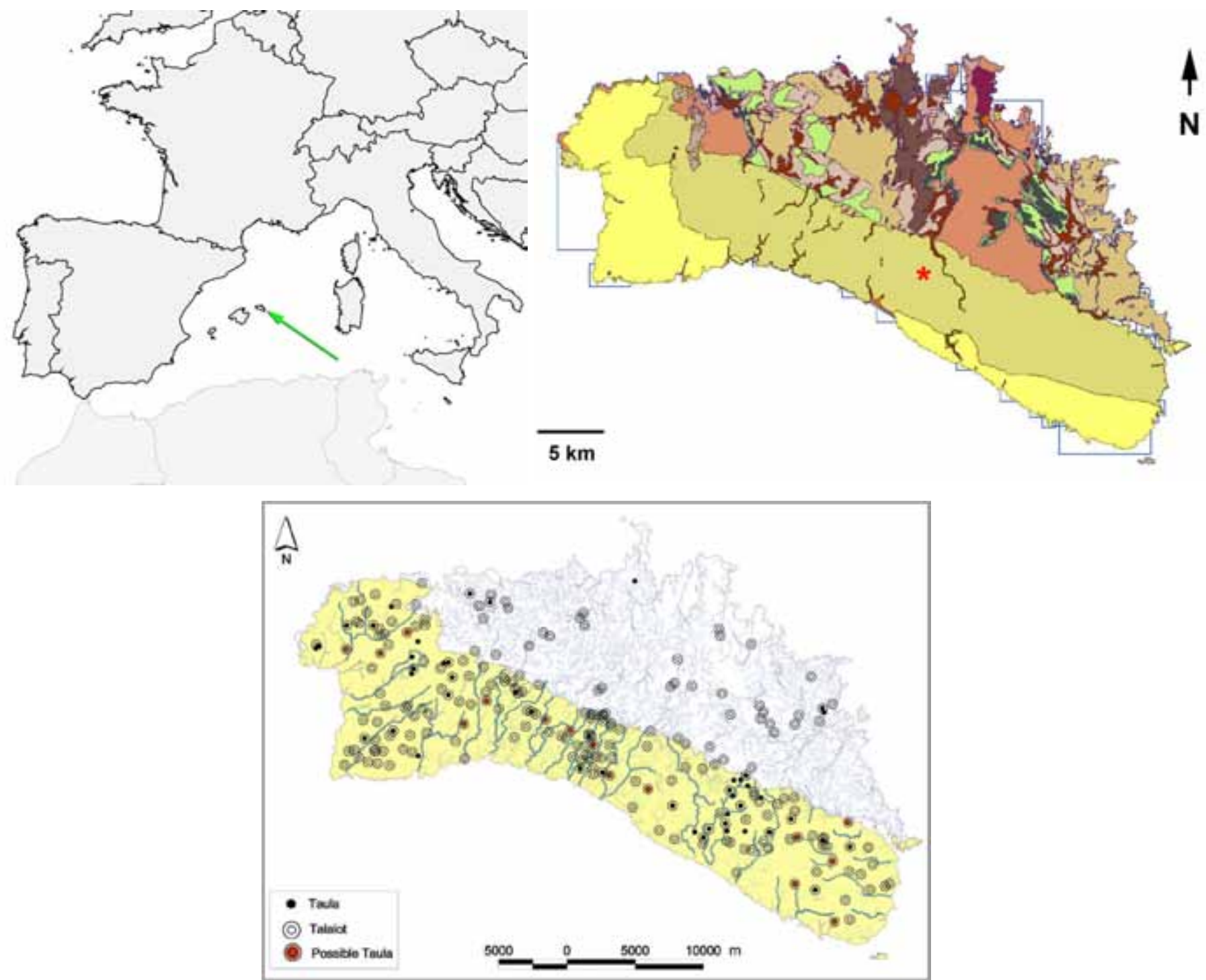

Figure 1. (a) Location of Menorca in the Western Mediterranean (arrow). (b) Schematic view of the major aspects of the geology: the entire southern half of the island is covered by generally upper Miocene limestones (yellow and beige colours) of various facies ("Facies de lagoon. Calcarenitas; Taludes arrecifales; Predominio de bioconstrucciones"), whereas the northern half is comprised of Paleozoic and Mesozoic siliclastic rocks and dolomite. The site of Torre d'en Galmés is shown by "*". (Geological map from Infrastructura de Dades Espacials -IDE, Consell Insular de Menorca, but see (Rosell et al., 1989). (c) Distribution of taulas and talayots between the 650 BCE and 123 BCE (from Gornés et al., 2004). The location of these sites largely coincides with outcrops of generally upper Miocene limestone in the southern part of the island.

Figura 1. (a) Localización de Menorca en el Mediterráneo occidental. (b) Esquema de la geología de la isla: la mitad sur está cubierta por calizas del Mioceno mientras que la parte norte son rocas siliclásticas y dolomitas del Paleozoico y Mesozoico; ubicación del yacimiento de Torre d'en Galmés marcado con un *. (c) Distribución de las taulas y talayots entre el 650 BCE y el 123 BCE (según Gornés et al. 2004). La ubicación de los yacimientos coincide con los afloramientos de caliza del Mioceno en la parte sur de la isla. 
and Higuera, 2005; Juan and Pons, 2005; Soberats et al., 1984). Interestingly, although all Talayotic structures were built with a specific type of local limestone, very little attention has been paid to the provenience of these raw materials and quarrying techniques. A similar lack of interest has occurred regarding the inter-building spaces in the settlements or non-architectural environments. These 'inter-architectural' areas have considerable potential for elucidating the complete fabric of the living space and can serve to weld activities within individual dwelling spaces to communal areas. In this paper we present some initial results of our excavations at Torre d'en Galmés, Menorca, coupled with detailed field observations and micromorphology to demonstrate quar- rying both within and outside the buildings. This evidence provides a greater understanding of the large site complex as a whole, which ultimately can be related to other sites in the Balearic Islands. Although the information that we present here is not meant to be a detailed, comprehensive study of all types of building stones from Torre d'en Galmés or other sites on the island, we do hope that it will bring to the attention of Mediterranean archaeologists some of the important and widespread issues raised here.

\section{The Talayotic site of Torre d'en Galmés and its setting}

The Talayotic culture takes its name from the word
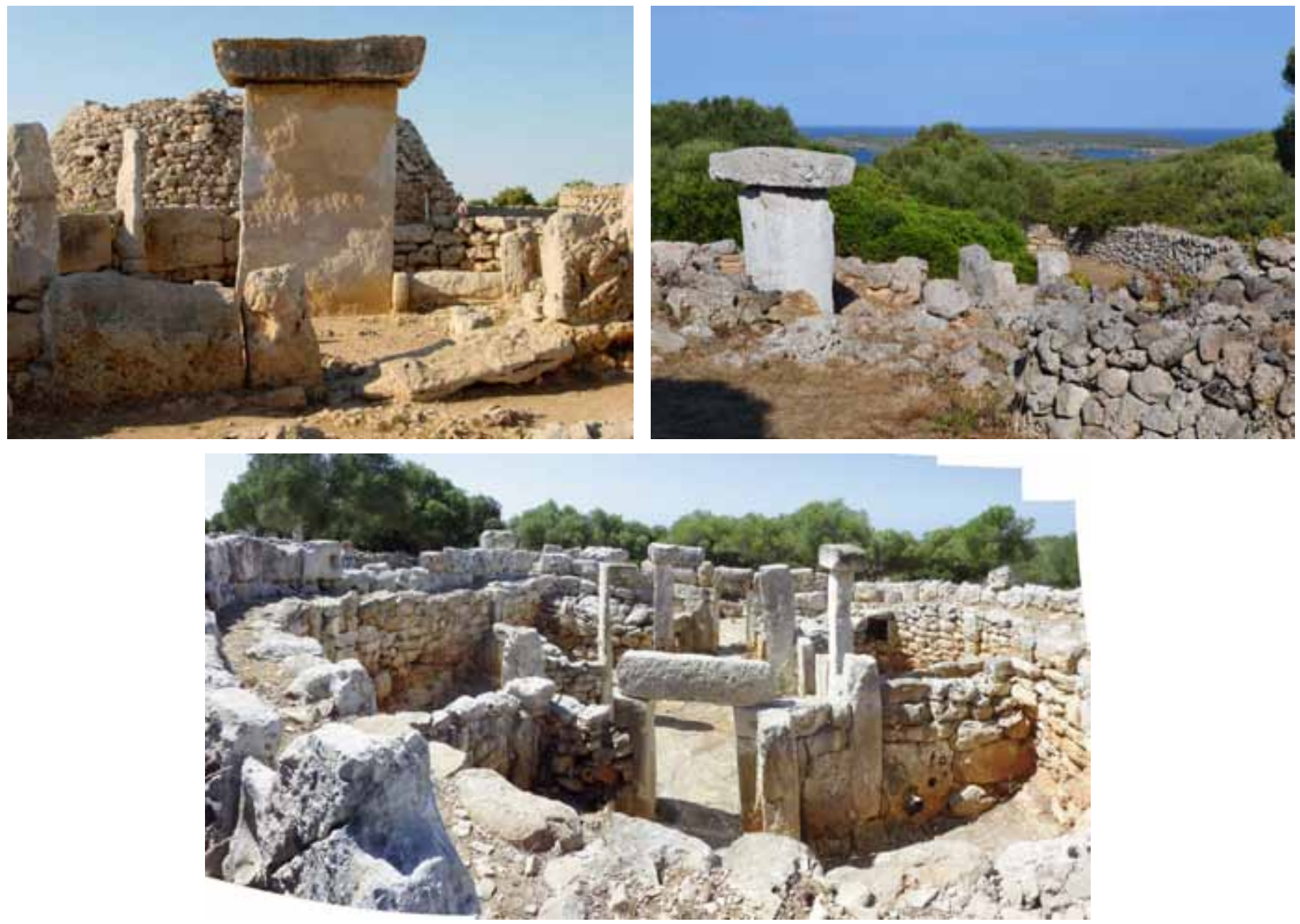

Figure 2. The Talayotic culture is derived from the word "talayot" -from the Arabic, watchtower-. The taula precinct, which was a religious building, consists of a huge central pillar that supports a perpendicular slab -the actual taula. (a) Talayot and taula, in the background and foreground, respectively, at the site ofTrepucó; (b)Taula at site of SaTorreta deTramuntana; (c) Cartailhac House atTorre d'en Galmés showing a mixture of smaller limestone blocks against the walls and long quarried blocks for uprights and lintels.

Figura 2. (a) Talayot y taula del yacimiento de Trepucó; (b) Taula de Sa Torreta de Tramuntana; (c) Círculo Cartailhac de Torre d'en Galmés en donde se aprecia los diferentes tipos de aparejo utilizados para la construcción del edificio, desde pilares a sillares cuadrados o rectangulares. 
"talayot", an evolution of the Arabic term for watchtower (Figs. 2 and 3). These numerous watchtowers and the construction of large settlements are the main characteristics of the beginning of the Iron Age in Menorca. The new "cities" were primarily built inland, had a privileged control of the territory and, for the most part, were surrounded by walls. They had similar internal urbanization with talayots and sanctuaries -taula precincts- along with large domestic complexes, working spaces, storage areas, and cisterns (Pérez-Juez, 2011, Pérez-Juez, 2013, Rosselló Bordoy, 1986, Sintes and Isbert, 2009). From the $5^{\text {th }}$ century BC, the heavy influence of Carthaginian trade flooded the islands with Punic amphorae and other material -the post-Talayotic period- but the architectural techniques remained the same: stone megalithic buildings quarried in situ. The destruction of
Carthage in 146 B.C., followed by the rapid Roman expansion over Punic dependencies resulted in the conquest of the island in 123 B.C., and marked the end of the Talayotic and post-Talayotic cultures.

Torre d'en Galmés is the largest Talayotic site on the island of Menorca and is situated -as are the majority of the sites- on the southern half of the island (Migjorn) (Fig. 1c). The site sits on an undulating and partially dissected limestone plateau at an elevation of $\sim 125 \mathrm{~m}$ a.s.l. The bedrock here consists of a compact well-cemented and jointed Upper Miocene Tortoniense-Mesiniense limestone, (Unit 2b bioconstructional facies, and Unit 1, reef talus facies (Rosell et al., 1989). These rocks are cross-bedded, and within the limits of the site, they exhibit two sets of joints: a more pronounced set of joints occurs in and around Building 2 at the site, and is oriented roughly $N 70^{\circ} \mathrm{O}$;
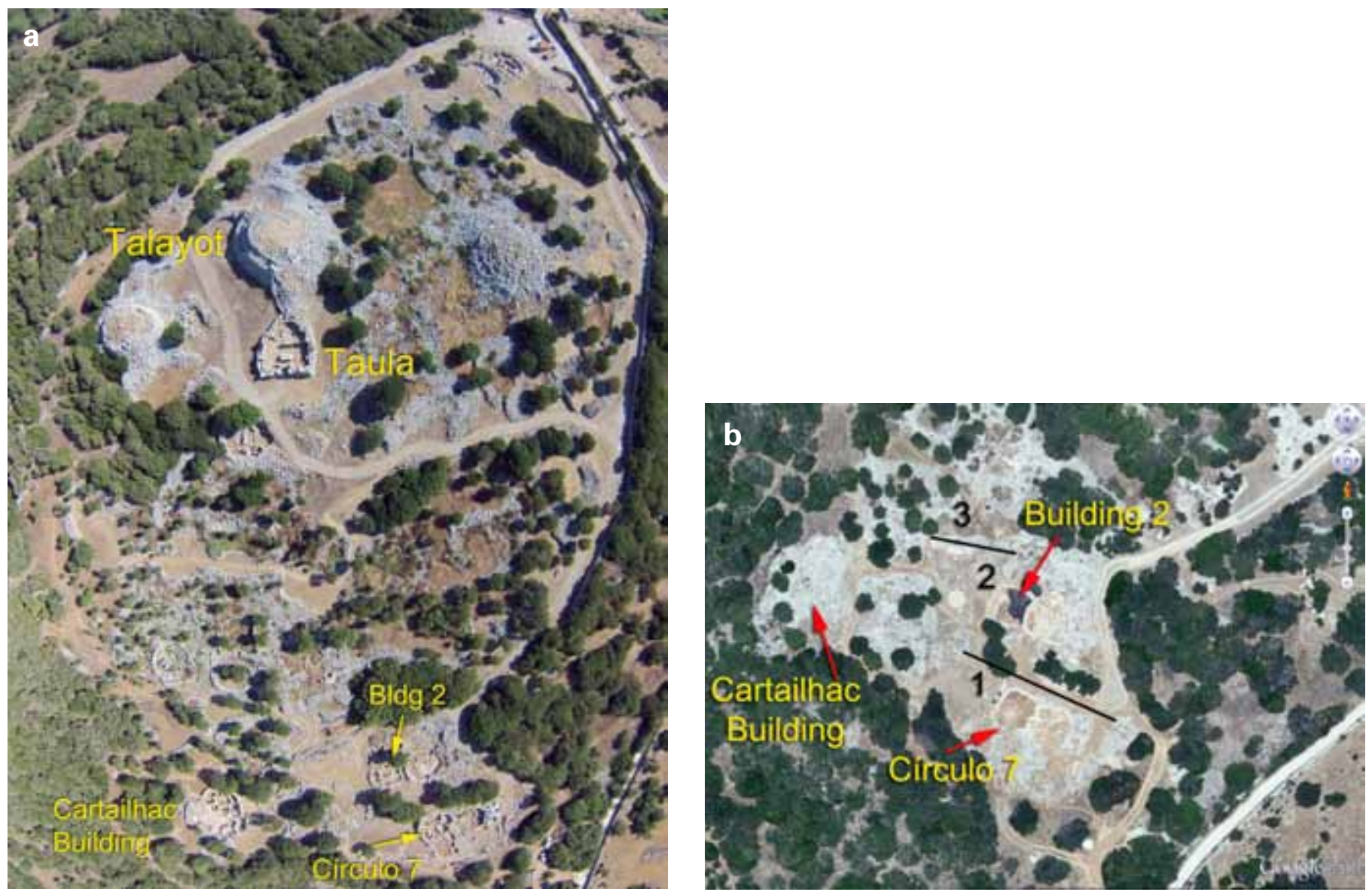

Figure 3. (a) Aerial view of the site ofTorre d'en Galmés, showing the locations of Talayot, Taula, Building 2, Cartailhac Building and Círculo 7. Photograph taken in 2013, courtesy of Amics del Museu de Menorca-Carlos Mascaró. (b) Photograph of southern part of site Torre d'en Galmés with location of buildings shown in (a) (Google Earth photograph, 2007). The black lines indicate the limits of flat areas (terraces), which are numbered. These terraces, exposed between architectural structures, were quarried and also would have served as public spaces after quarrying (see text).

Figura 3. (a) Vista aérea del yacimiento de Torre d'en Galmés. (b) Detalle de la parte sur del yacimiento con la localización de los edificios. Las líneas en negro indican las diferentes terrazas utilizadas para la extracción de la piedra caliza (Google Earth, 2007). 
in addition, a more minor set of joints, which are more variable in orientation, range from about $\mathrm{N} 10^{\circ} \mathrm{E}$ to $\mathrm{N} 20^{\circ} \mathrm{E}$ (vid. infra).

The highest part of the site is where the talayots and taula are found ( $125 \mathrm{~m}$ a.s.I.) (Fig. 3a). The rest of the structures slope down towards the south, and it is clear that the settlement expanded downslope from the top of the hill towards the south over a period of eight hundred to a thousand years during the first millennium BC. Moreover, in the lower part of the site, it is possible to delineate three broadly visible stepped surfaces, which are relatively flat and covered with fine sediment (Fig. 3b). These "terraces" represent some of the largest open spaces within the confines of the site.

At present, the soils in this part of the island and surrounding the site are chromic cambisols (Consell Insular de Menorca, Infrastructura de Dades Espacials Menorca (2015), red clayey silty sand, which exhibit incipient horizon differentiation as shown by changes in colour, structure, or carbonate content. The cambisol designation is clearly a reflection of modern conditions, since most of the soils have undergone various stages of erosion at least since Talayotic times (vid. infra). This erosion is evident from the fact that bedrock punches up above the ground level and only patches of soil are found today on the surface, primarily in micro-topographic depressions.

The western flank of the site is delimited by a small ephemeral stream (barranco, in Spanish). On the eastern side, about two kilometers to the east, a major drainage stream -Barranco de Cala en Porter- drains the northern part of the island and dissects the limestone plateau forming a striking canyon before it reaches the sea at Cala en Porter on the south coast. Exposures are relatively poor in this drainage but the sediments appear to be gravelly and contain reworked soil material.

\section{Evidence of quarrying and extraction of rock within the site}

In recent decades, the Talayotic culture has attracted a considerable number of archaeological projects, most of which have been focused on the excavation of large public buildings -talayots and taula precinctsto elucidate their age and use (Rosselló Bordoy et al., 1984). There have also been detailed studies of cultural remains, such as local and imported pottery, and figurines of deities found in the taula sanctuaries. The architecture has been extensively described and heavily restored, and most recently, the nature of domestic spaces has been the focus of new research projects (Ferrer et al., 2011; Sintes and Isbert, 2009). However, little consideration has been given to the ideas of urbanism as a whole, or to the building techniques and raw materials needed to build these impressive structures.

All Talayotic structures are built in stone. The building blocks have different shapes and sizes varying from cubic to square ashlar stones to megalithic uprights (Fig. 4). Some efforts to locate the quarries and quarrying techniques have been carried out in the
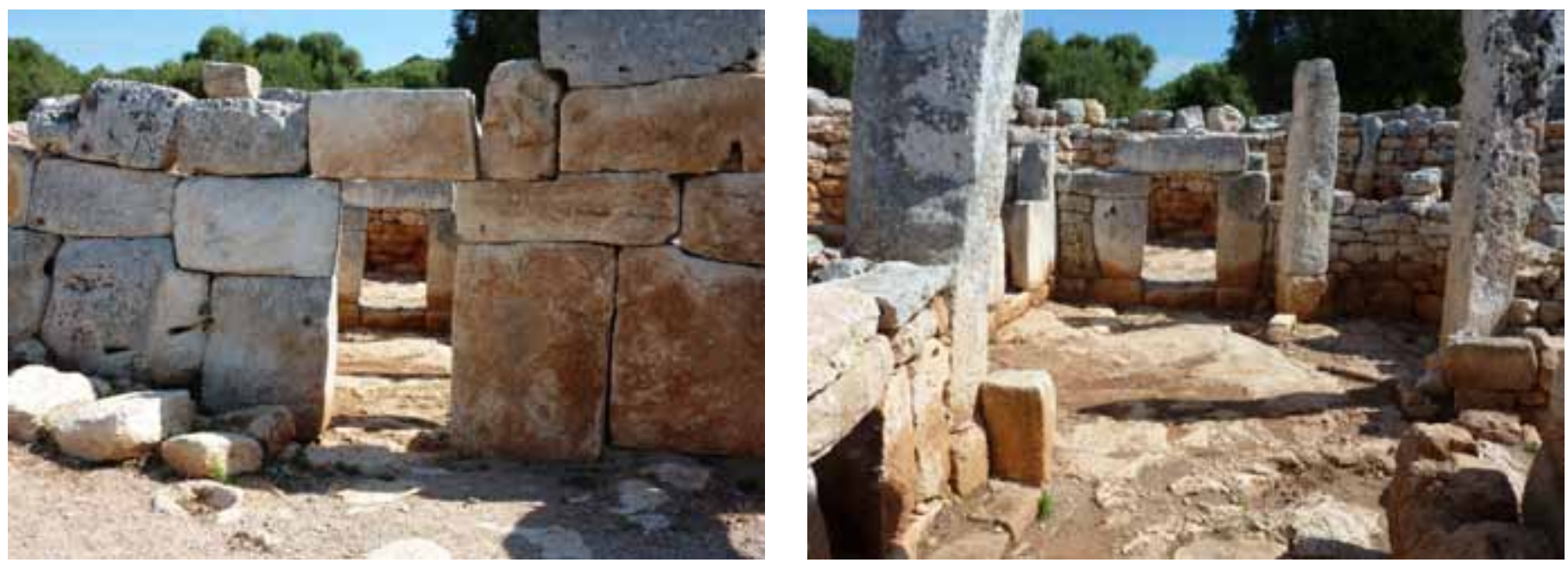

Figure 4. Quarried limestone blocks. (a) Equidimensional to tabular blocks in Cartailhac Building. (b) Elongated rectangular vertical uprights used possibly to support the roof of the structure; square ashlar stones are visible along the back walls.

Figura 4. (a) Diferentes bloques de caliza en el Círculo Cartailhac. (b) Pilares en el patio central, utilizados seguramente como soporte de la cubierta, asi como detalle de los sillares de los muros interiores. 
past, both in Menorca and Mallorca (GarcíaAmengual, 2012; Kopper and Rosselló-Bordoy, 1974; Serra, 1963), exploring mostly areas at the limits of the sites. In contrast, historical quarries scattered throughout the island have attracted the interest of scholars, as well as the study of ethnographic exploitation of the limestone (e.g. TUTV (2014). Despite this omission, remains of quarrying are abundantly evident in the Talayotic landscape, both within structures and open spaces in the settlement, as well as in the surrounding areas outside the site limits. A casual inspection of these sites reveals how much of the surface area in these terrains was modified in prehistoric times.

\section{Evidence within the buildings}

The study by Serra 1963, noted that local quarrying of bedrock should be present in the areas around Talayotic sites, but her foot survey was restricted to areas outside the buildings. Nowadays, however, the remains of quarrying activity can be noted in all the excavated buildings, such as the ones at Torre d'en Galmés: Building 2, Círculo Cartailhac, and Círculo 7 amongst others (Fig. 3b). These vestiges include the lifting of isolated limestone blocks, levelling the floors, and cutting back the sloping bedrock (Figs. 3 and 5).

Figure $5 a$ is an aerial view of part of Building 2 at Torre d'en Galmés, where rectangular blocks were removed from the floor of the building. In this structure, as in similar buildings, as well as in open spaces within and outside the limits of the site, inhabitants exploited the geological properties of the bedrock to quarry it. The nearly rectangular system of roughly EW/N-S joints (vid. supra) provided the natural surface outline of the blocks (Figs. 5a and 5b). Moreover, the reefal limestone is cross-bedded, and planes of weakness along sets of cross-beds furnished the vertical, third dimension, allowing for the relatively easy extraction of blocks along the bedding planes. Interestingly, in cases where the bedrock was not sufficiently jointed and thus too massive, it was not possible to remove any blocks, and builders did not attempt to quarry the bedrock; instead they left entire areas and knobs of limestone sticking out above the floor level. This situation is readily observable in the NE quadrant of Building 2 (Figs. 5b, 5c, 5e and 5f) where the irregular and upward sloping topography of the partially quarried floor of the building is revealed in two topographic profiles shown in Figure 5e. In section $A-A^{\prime}$ the bedrock rise mentioned above illustrates the unevenness and sloping nature of the floor level, as well as the areas that were quarried; similar depressions are seen in section $\mathrm{B}^{-} \mathrm{B}^{\prime}$. In any case, many of these depressions were later filled with anthropogenic debris (broken pottery, bones, and charcoal), which served as a means to level the floor (Fig. 5g) (Pérez-Juez et al., 2011). Such infilling took place during the initial stages of building construction and occupation. The same can be observed in other buildings at Torre d'en Galmés, as well as at the taula precinct of another Talayotic site, Torralba d'en Salord (Fig. 6).

\section{Evidence from open spaces}

The evidence of quarrying can be found in many

\footnotetext{
Figure 5. Quarrying activities within Building 2 from the site of Torre d'en Galmés, Alaior, Menorca. (a) Quarried areas are shown by yellow arrows, whereas red arrows point to massive/unjointed limestone that was not quarried and hence the floor rises sharply to the upper right-hand area of the photograph (cf. Fig. 5e). (b) Rectangular hole produced by quarrying of a block from the floor of the building. (c) Contour map showing the irregular surface and quarried locales within the building (green arrows). Notice the steep sloping floor in the upper right quadrant, which shows that the inhabitants did not succeed to level the bedrock here. The bedrock in this part of the building was too massive and was not fractured enough to enable the extraction of a block (see Fig. 5a). (d) Outline of Building 2 showing location of two topographic transects: A-A' and B-B'; (e)Topographic profile along lines $A-A^{\prime}$ and $B-B^{\prime}$. Note the rise of bedrock at the back of Building 2 as shown in profile $A-A^{\prime}$ (note that $E$ and $W$ directions are reversed). The arrows in both profiles point to areas, which were quarried and provided raw materials for the walls. The quarrying also served to level the floor to make it suitable as a living space. (f) Rear area of Building 2, looking westward and showing locations of quarried areas (arrows); in the foreground is massive unjointed bedrock that was not quarried $(X)$. Behind this, note the vertical face of the bedrock that forms the rear of the building upon which blocks were laid to create the rear wall, a common feature in these buildings. (g) Close up of a quarried depression (arrow) at the north end of Building 2 filled with broken pottery, bones, and charcoal.

Figura 5. Extracción de piedra caliza en la Casa 2 en Torre d'en Galmés, Alaior, Menorca. (a) Las flechas amarillas señalan las zonas en las que se extrajeron bloques mientras que las rojas indican las zonas sin diaclasas, demasiado masivas y difíciles de tallar. (cf. Fig. 5e). (b) Negativo de la extracción de un bloque. (c) Mapa con curvas de nivel en el interior del edificio (flechas en verde). Los diferentes desniveles se deben a la imposibilidad de extraer la piedra en ciertas zonas por la inexistencia de diaclasas. (Fig. 5a). (d) Ubicación de las secciones $A-A^{\prime}$ y $B-B^{\prime}$ dentro de la casa; (e) Sección de los cortes $A-A^{\prime}$ y $B-B^{\prime}$. (f) Parte trasera del edificio en donde se observa la ubicación de extracción de material (flechas) así como la roca madre masiva dejada sin extraer $(X)$. $(\mathrm{g}$ ) Detalle de uno de los negativos rellenos de fragmentos de cerámica huesos y carbón.
} 

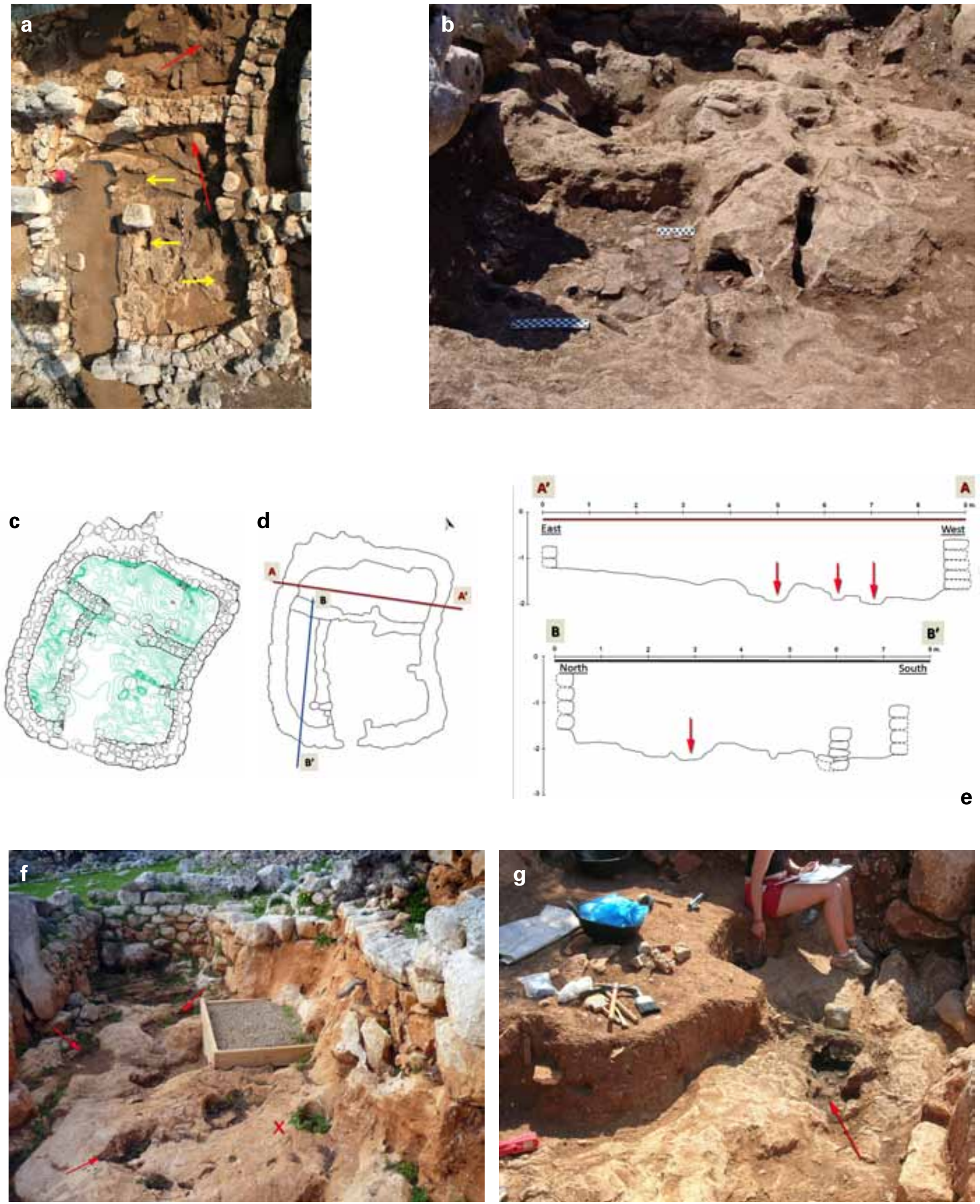

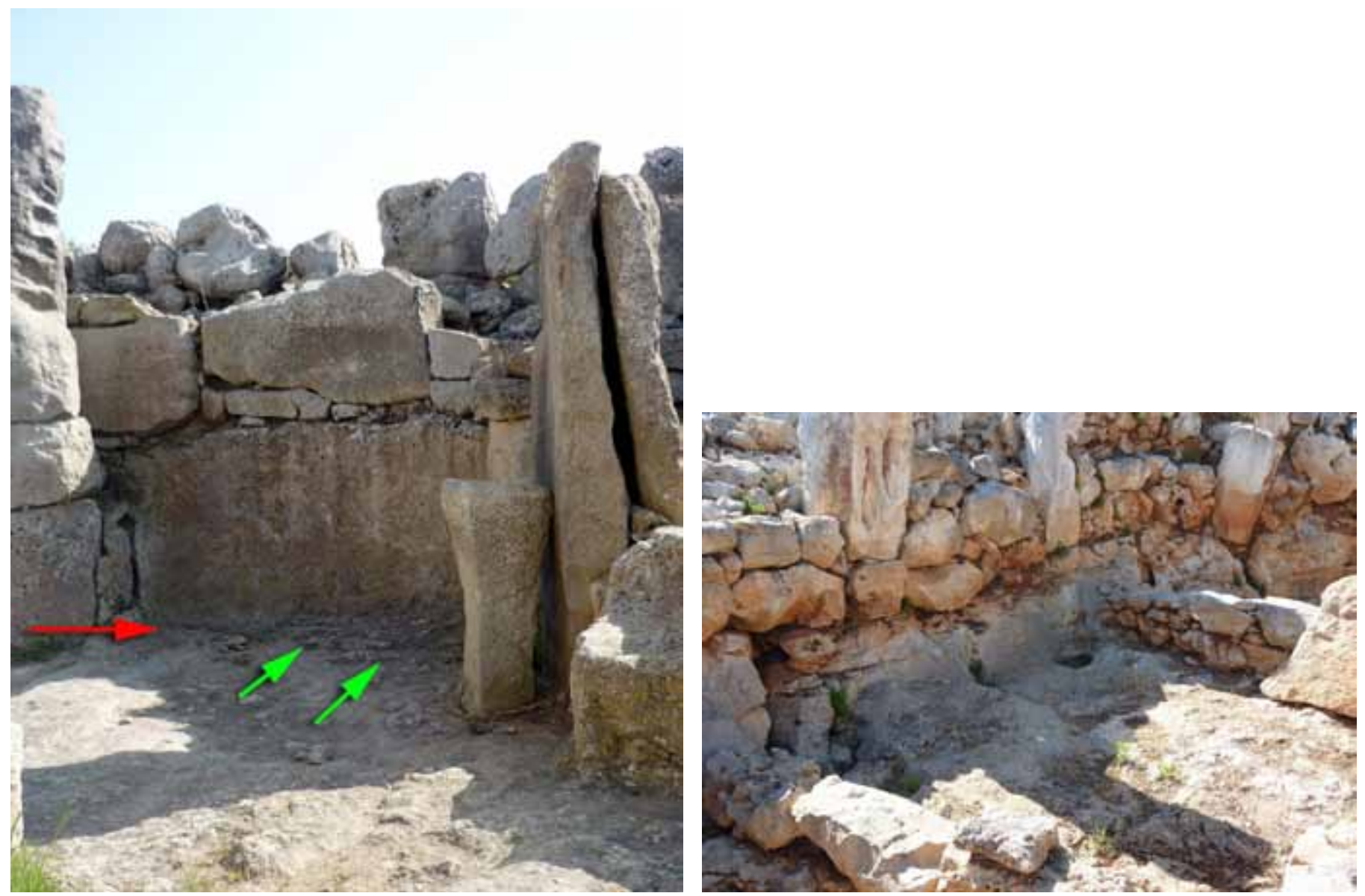

Figure 6. (a) Taula precinct from the site of Torralba d'en Salord, showing the similarity in levelling floors as in Figure 6b. (b) Cut floor and wall of domestic structure in the southern part of Torre d'en Galmés.

Figura 6. (a) Recinto de taula del yacimiento de Torralba d'en Salord con el mismo sistema constructivo mencionado para Torre d'en Galmés; (b) Círculo 7 de la parte sur de Torre d'en Galmés con idéntico patrón.

places on the island, and its vestiges are visible all over the Menorcan landscape, both within the entire site complexes and margins, as well as beyond the boundaries of the sites. At Torre d'en Galmés, indications of removed blocks in between architectural spaces are quite visible, although vegetative cover and less open expanses make their recognition more difficult. As an example, we note an open area next to Building 2 on the surface of Terrace 2, (Fig. 3b. 1), south of and below the terrace of Trench B (vid. infra), a GPR survey report in 2002 indicated that, "...the surface in the survey area is dominated by lumpy outcrops of limestone up to 0.3 meters in height..." (Dayton, 2002). When it was excavated immediately after the GPR survey, the exposed surface seemed to be simply an uneven one that was not interpreted other than an "open space." In retrospect, and after our more extensive examination ofTorre d'en Galmés and other Talayotic sites, we see that both the survey and following excavation at that time missed the significance of this particular area as having been a quarried open space between buildings.

In addition, quarried space can be observed even next to walking paths and small patches all over the site area (Fig. 7a) where squared areas of jointed bedrock crop out. Similar evidence is visible at other sites, such asTorralba d'en Salord, where a large open space south of the talayot show the striking volume of removed blocks from the area (Fig. 7b).

During the field campaigns of 2012-2014, the Boston University field school excavated Trench B (9 x $1.5 \mathrm{~m}$ ) in one of the flat terrace areas northwest of Building 2. The goal of excavating the trench was to discern the nature and use of the terrace, an open space surrounded by numerous domestic complexes (Fig. 3b. 2). The excavation revealed isolated knobs of bedrock surrounded by finer matrix materials. It became evident only at the end of the second season 

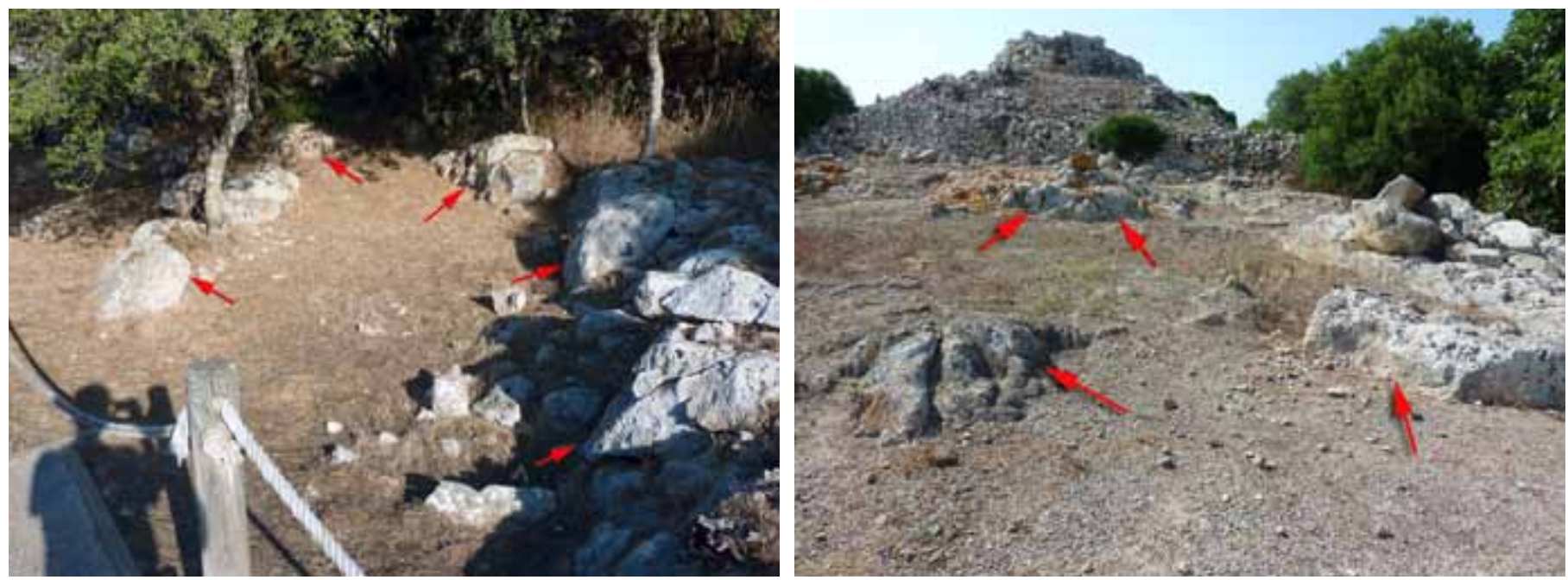

Figure 7. Evidence of quarrying from open spaces. (a) Quarried space next to walkway in the site of Torre d'en Galmés; arrows delineate areas removed in quarrying and the bedrock that remains. (b) Quarried areas and remaining bedrock knobs (arrows) from the site of Torralba d'en Salord.

Figura 7. Evidencia de extracción de piedra en espacios abiertos señalados con flechas rojas en el (a) yacimiento de Torre d'en Galmés; (b) yacimiento de Torralba d'en Salord.

that this 'knobby' microtopography represented the remains of unquarried space. The remaining depressions between these microtopographic highs had been filled immediately after, with what appeared to be in the field a mixture of calcareous sediments that contained trimming flakes, bones, pottery, and what we thought to be ashes.

These potential ashy deposits were subjected to micromorphological analysis, whereby intact blocks of sediments are removed, hardened with resin, and sliced with a rock saw. The $50 \times 75 \mathrm{~mm}$ slices were glued on to glass slides and then prepared into petrographic thin sections (Courty et al., 1989; Goldberg and Macphail, 2006). Interestingly, only traces of ashes were found in the thin sections, in the form of rhombs of calcite (Canti, 2003). On the other hand, the matrix is rich in sand- and silt-sized clasts of calcite derived from the surrounding limestone, and it is clear that these white calcareous grains provide the (whitish pink, powdery) "ashy" appearance of these sediments in the field. The origin of these calcite clasts is most reasonably a product of the quarrying activity, since the natural soils in this part of the site do not generally contain calcite (or this amount of it) or at least not with the sandy/silty aspect of the Trench $B$ sediments. Thus, an anthropogenic source of this calcite must be sought (Fig. 9).

Similar types of calcareous 'ashy' deposits occur elsewhere in the trench, where large blocks of limestone had been extracted and backfilled shortly after with thicker "ashy" anthropogenic deposits that were more organic rich and contained charcoal. The contemporaneity of the quarrying and the depositional infilling is demonstrated by the pottery typology and the radiocarbon date of $2540 \pm 30$ a BP (BETA-356718) on bone from the deposits (Fig. 8).

\section{Discussion}

The above results reveal the extensive degree of quarrying at the site of Torre d'en Galmés. This activity has a number of important ramifications that touch upon issues such as raw materials, the changes of the landscape resulting from quarrying and construction, the urbanism of Talayotic settlements and the use of open and built space within these prehistoric sites, and building technology and quarrying methods.

\section{Geology and raw materials}

Although there are different types of rock on the island, all the Talayotic sites on the southern half of the island were built using the same hard limestone from the talus reef facies of the Upper Miocene, Tortoniense-Mesinense (Rosell et al., 1989). The few sites located in the northern part of the island (e.g. Sa Torreta de Tramuntana) follow this same strategy of quarrying hard limestone, but in the north they exploited the well indurated Jurassic limestone that crops out more locally there. The soft Upper Miocene 

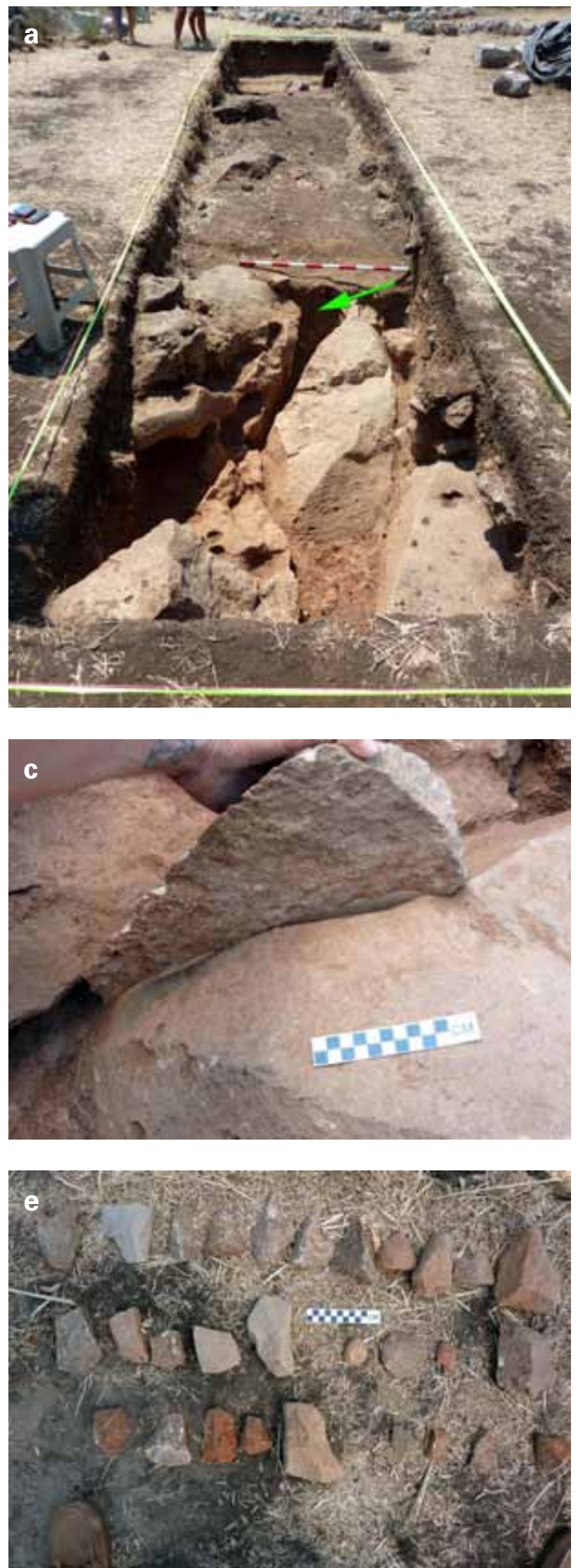
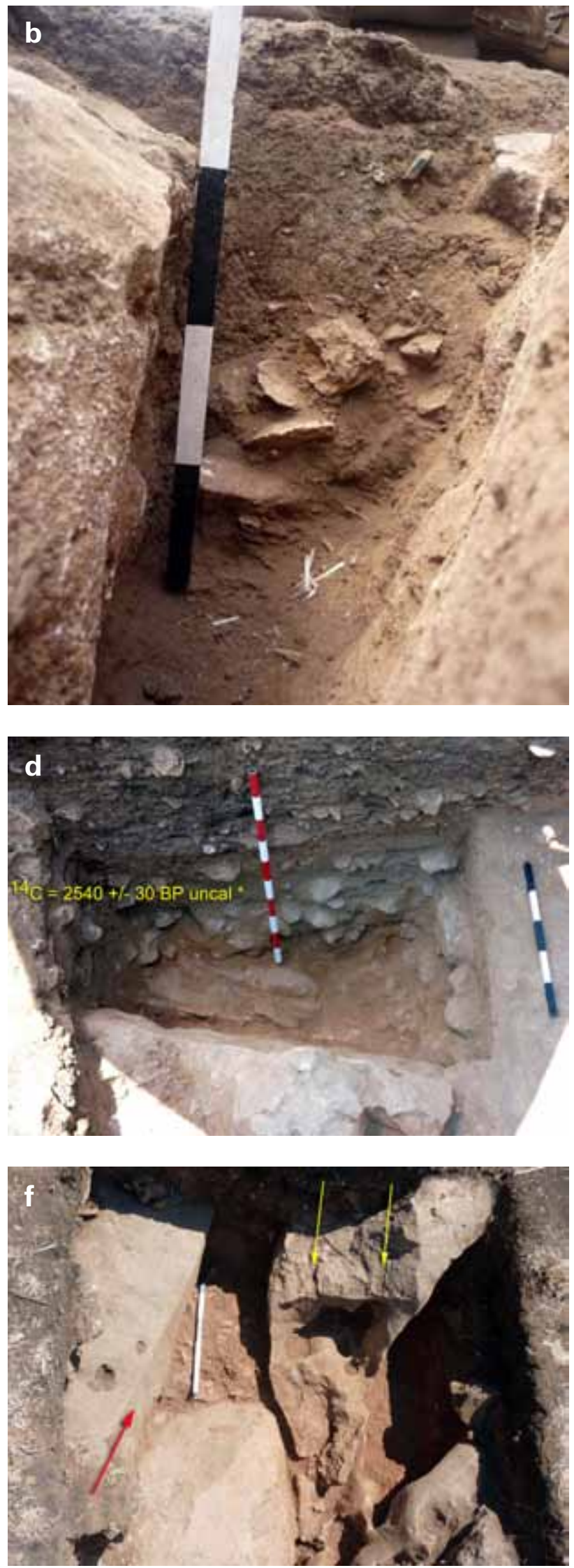
lagoonal facies (colloquially called piedra de "marés") that is restricted to the southern half of the island, was used from Roman times to the present (vid. infra).

These hard rock materials were utilized extensively both in and outside the settlements (Fig. 10). Any outcrop was exploited, from the ones inside the houses to those outside the buildings and site areas. While some quarries have been identified outside the settlements -e.g. Serra (1963)- builders also used the most immediate outcrops inside the houses and settlements. Although the sizes of the blocks are relatively small and variable in size within the constructions, the larger ones (e.g. the big pillars inside the buildings; see Fig. 2) were probably brought in from just outside, in the immediate surroundings of the sites. Beyond the confines of the site proper large quadrangular blocks (preconditioned by karstic dissolution of joint systems) were eminently suitable for central pillars within the buildings (Fig. 10).

\section{Changes in the pre-existing landscape due to quar- rying}

Talayotic domestic spaces -houses, storage areas, and working areas- all follow the same constructive building pattern: at each location, they would completely remove the soil off the bedrock and begin quarrying the limestone substrate, exploiting the natural joints and bedding (Pérez-Juez 2011). Then, the blocks would be extracted to form an external double wall filled in with rubble. Once the blocks were emplaced, they were trimmed, with the flakes/chips accumulating on the surface. All these negative depressions show the extraction of raw materials to build the walls and demonstrate the need to level the floor to be used as a living space.

An interesting consequence of the extensive quarrying outside the site is the effect on present and past soil cover: removal of these blocks would have disrupted the existing terra rossa soil and not only would have cleaned it from above the bedrock but also would have displaced it; the removed soil might also have been used for making pottery, roofing, or plastering the buildings. Such soil "rearrangement" and anthropically-induced mobility could have also led to an increase in overall destabilization of the soil surface, leading to increased soil erosion. In addition, we need to consider the consequences of such disruptions for agriculture, as soil cover would have been locally missing, or would have occurred only as localized patches. In any case, the use of present-day distributions of soil types on this part of the island must be viewed with caution when looking into past soil use, as they are not representative of the former soil landscape.

\section{Talayotic settlement layout}

Quarrying influences site layout, defining the spaces built and the ones left open. In the southern part of Torre d'en Galmés, our recent excavations have shown that the open areas in between domestic spaces are quarrying areas, where raw materials were removed to provide building materials. These areas were back filled (Terrace 1; Fig. 3), left open

Figure 8. Open space within the Talayotic site ofTorre d'en Galmés. (a)Trench B - situated on the Terrace 3 (Fig. 3b) - exposed an irregular, undulating surface of the limestone bedrock, a result of ancient quarrying. The photo looks westward along the trench and shows in the foreground partially quarried blocks; the arrow points to the location of the profile in Fig. $8 \mathrm{~b}$. In the middle ground, two knobs of quarried bedrock protrude above the partially excavated surface. At the far end, ancient quarrying extended deep below the surface, producing an area that was later filled in (see Fig. 8d). (b) Detail of quarried joint shown in Fig. 8a. The cavity is filled with a mixture of trimming flakes and rock fragments in a calcareous sandy silty matrix. (c) A large flake detached from the bedrock in this east end of the trench. (d) Deeply quarried area at the west of the trench looking toward the south. At the bottom of the photograph quarried bedrock remains - note the linear jointing - whereas the profile on the south side of the trench shows a mixture of massive calcareous deposits and angular, platy clasts of limestone, many of which are trimming flakes produced by the quarrying (see Fig. 8e). Note the $\sim 80-100 \mathrm{~cm}$ of relief in the bedrock, indicated by the height of the top of the bedrock in the lower part of the photo, and that of the bedrock exposed in the base of the excavated area upon which the red meter rests. This filled-in relief became a public or circulation space surrounded by different domestic complexes and the surface of this fill coincides with the level of Terrace 3 in Fig. $3 \mathrm{~b}$. The position of an uncalibrated ${ }^{14} \mathrm{C}$ date of $2540 \pm 30 \mathrm{BP}$ is marked with an asterisk and accordingly shows that the infilling took place immediately after the quarrying activity. (e) Trimming flakes produced by quarrying and found in the ashy fill of the sediments in Figure 8d. (f) East end of trench showing chisel marks (yellow arrows); the red arrow is aligned along a smooth joint in the bedrock, to the right of which bedrock has been quarried.

Figura 8. Espacio abierto en una de las terrazas de Torre d'en Galmés. (a)Trench B en donde se observa la superficie irregular resultado de su uso como cantera. La flecha verde indica el detalle de la figura $8 \mathrm{~b}$. (b) Detalle de la talla de piedra con los restos de las lascas provenientes del retoque de los bloques extraídos. (c) Una lasca de uno de los bloques tallados, todavía in situ. (d) Una de las zonas extensamente tallada en la parte oeste de la cata. En la parte de abajo, se observa la roca madre y el relleno inmediato con depósitos calcáreos de aspecto grisáceo que los hace fácilmente confundibles con cenizas. La datación de uno de los huesos proveniente de este depósito dio una fecha sin calibrar de $2540 \pm 30$ BP. (e) Lascas de la talla dentro del depósito grisáceo. (f) Marcas producidas por el uso de un cincel (flechas amarillas). 

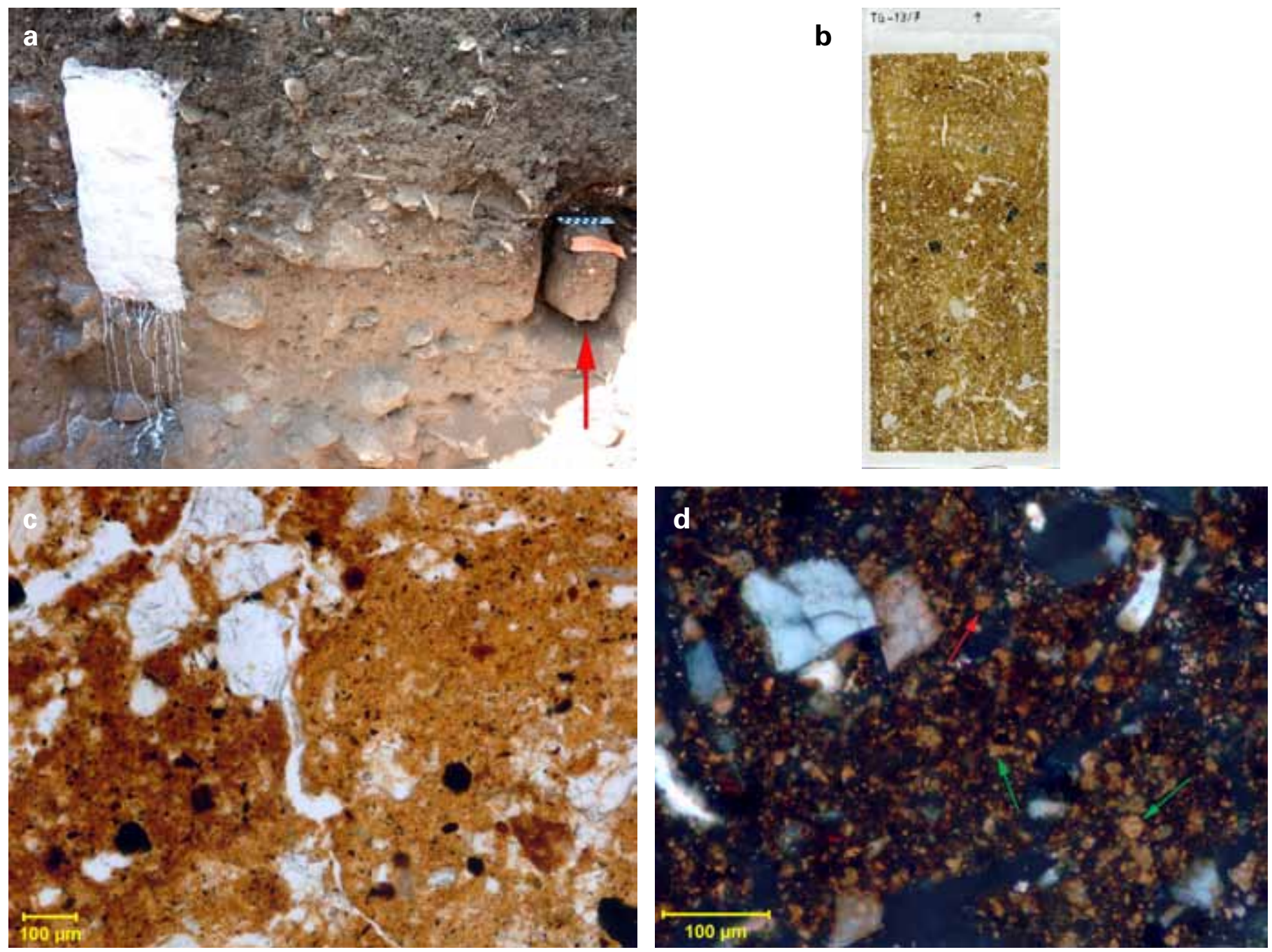

Figure 9. Deposits from west end ofTrench B. (a) South profile showing location of the micromorphology sample (arrow); (b) Thin section scan of sample TG-13-7 from calcareous deposits in the lower part of Trench B - length of thin section is $137 \mathrm{~mm}$; (c) Photomicrograph of sediment shown in Figure 9b with yellow brown matrix enclosing coarse grains of quartz (Q) and limestone (LS)(plane-polarized light $\mathrm{PPL}$ ); (d) Same view as at left but in cross-polarized light (XPL). In this view most of the yellow silt grains (green arrows) are composed of calcite derived from limestone, reasonably associated with quarrying, as the soils in this area are not rich in calcite silt. The red arrow is a rhomb-shaped grain of calcareous wood ash. The micromorphological results show that the white, powdery nature of the sediments is due to 'limestone dust' and not fire-derived ashes, which we had hypothesized in the field.

Figura 9. Depósitos de la parte oeste de la Cata B. (a) Perfil sur con flecha señalando la ubicación de la muestra; (b) Lámina delgada de la muestra TG-13-7, en donde se observa depósitos calcáreos; (c) Fotomicrografía de la figura 9b con matriz marrón amarillenta con cuarzo (Q) y caliza (LS) (LPP); (d) lo mismo que $9 b$ pero con luz polarizada cruzada. Las flechas verdes señalan limo calcítico proveniente de la talla de la caliza. La flecha roja señala los restos de ceniza. Los resultados del análisis micromorfológico revelan que los depositos blanquecinos no provienen de la combustión de material sino de la talla de la caliza.

(Terrace 2; Fig. 3), or used as cavities (for storage and other purposes; Terrace 3; Fig. 3). In any case, they were left as public open spaces where circulation between buildings was possible.

The terraced surfaces that we observe are part of the geomorphology of this part of the island and are associated with the erosion of the Miocene bedrock, which in open fields are characterized by stepped topography. AtTorre d'en Galmés, thee terraces were exploited to quarry materials, thus defining the layout of the settlement by removing the soil and quarrying the stepped surface.

The open spaces in between built complexes are the object of our current research. Recent excavations of domestic complexes in the southern part of the site (Círculos 1, 2, 7, and Círculo Cartailhac; Fig. 3a) have demonstrated that open spaces existed between the areas that were left as non-built areas after they had 



Figure 10. Quarrying beyond site limits. (a) Jointed limestone ca. $300 \mathrm{~m}$ SE of Building 2 (Fig. 2); meter scale is $50 \mathrm{~cm}$. Such blocks are readily available for quarrying, as shown in (b), which is ca. $50 \mathrm{~m}$ away and shows the area in which some blocks have been removed (delineated by arrows).

Figura 10. Talla de bloques en las inmediaciones del yacimiento. (a) Sistema de diaclasas a unos $300 \mathrm{~m}$ al SE de la Casa 2 (Figure 2); escala: $50 \mathrm{~cm}$. Los bloques aparecen listos para su extracción, tal y como se observa en la figura $b$.

been quarried. Whether these spaces had been used for communal use, as circulation areas, or as industrial workshops, still remains to be clarified. To date, the only space that has been studied is in the southern-most terrace of the site, where a number of depressions that were carved out of the bedrock were interpreted as "water collecting cisterns" (RossellóBordoy 1986: 68-72). However, in order to understand how past inhabitants defined the urbanism of Talayotic sites, as well as the functioning of built and non-built areas, much more needs to be learned from the quarried spaces left empty once the blocks were extracted.

So far we have not been able to identify traces of use levels in any of the test pits where quarries have been located. On the contrary, they all seem to be filled the same way: with dumps of stony calcareous, trimming flakes, bones and broken pottery.

\section{Methods of quarrying}

Quarrying techniques are still largely unknown or at least need clarification. Kopper and Rosselló-Bordoy (1974) proposed that fire could have been used to quarry the Talayotic site of Son Catlar. This situation is clearly not the case atTorre d'en Galmés, where there is no evidence of fire in the open areas we excavated. Furthermore, in light of the amount of the extensive quarrying activity at and around the site, it would have been difficult to find the amount of wood needed to extract so many blocks using fire. In addition, based on micromorphological observations of samples from Trench B and elsewhere at Torre $d^{\prime}$ en Galmés, there are only trace amounts of ash in the infilling deposits contemporaneous with quarrying activities, and thus, we have to discard this hypothesis. Finally, in Trenches B and E of the recent excava- 
tions at Torre d'en Galmés, some traces of chisel marks were identified, although as yet, no tools have been found (Fig. 8f). The fact that trimming flakes constitute the majority of the lithic component within the fill of all the areas excavated -both in the buildings and in open areas- demonstrate that they were using tools probably made of hard stones, perhaps similar to those found in the pre-Talayotic copper mine of Sa Mitja Lluna, in Illa d'en Colom, Menorca (Hunt et al., 2013). Wood wedges, iron chisels, and stone tools were probably the tools most commonly used but we only have studies for more recent times (Galván and Ferrer, 2000).

Since the time of the Roman conquest of the island (123 BC) the hard limestone is replaced by soft limestone (Miocene lagoonal marls - "marés"), which has yet to be found at any prehistoric site. All the buildings after this time were constructed in softer limestone, which is easier to quarry, transport, shape, and carve (Fig. 11). Because of their softness and massiveness, these recent quarrying operations involved the cutting out of blocks with chisels and saws. In contrast, at the Talayotic sites, quarrying practices exploited natural joints and bedding planes in the limestone -some clearly cut by chisels- to produce the building stones.

\section{Conclusions}

Torre d'en Galmés is a visually striking site, with its megalithic constructions and command of the landscape. There is much more going on than the cyclopean buildings that attract the interest of tourists and locals today. The site was occupied, abandoned, and reoccupied for over two thousand years, but it always kept the original layout and much of its building techniques. Interestingly enough, Torre d'en Galmés is not unique, as most of the Talayotic settlements of the island follow this same settlement and construction dynamic. However, what seems exceptional at Torre d'en Galmés is that the landscape has been so well preserved that it is possible to track more nuanced aspects of its history than has previously been attempted.

One aspect of this finer detail is the amount of quarrying that can be studied at the site which in turn opens up a whole new understanding of the Talayotic society. Quarrying of the limestone took place within the buildings for relatively small blocks. In the open public space and in nearby outcrops, large slabs were removed for pillars and outer walls of major buildings. Jointing of the bedrock played a prominent role in quarrying activities, which in turn is reflected in the shape of the buildings and their internal organization. At a larger scale, the overall site layout -structures, public spaces, open areas, circulation paths- is conditioned by the underlying bedrock and the way it was exploited.

From the standpoint of labour investment and organization, the removal of a medium-sized ashlar within a domestic structure might have been a household task (Fig. 5). On the other hand, the quarrying of the big slabs and uprights would have required a communal effort to lift and transport such large stones that commonly reach a length of ca. 2-3 m. The group effort needed to build taula precincts -sanctuaries- and other large buildings is a reflection of the complexity of Talayotic societies.

Some of these social implications have already been exposed by different authors (Bonanno et al., 1990; Kolb, 2005; Renfrew et al., 1974), who have developed theoretical models in Mediterranean islands with megalithic sites. Aspects such as social complexity, elites, specialized knowledge, and even common identity have been explained thanks to the study of these monumental remains in Malta and Corsica. However, most of these studies compare archaeological sites from different time periods and focus only on monumental buildings. Interestingly enough, open spaces and urban layout are left out of the study, so again, architecture is the main focus of these theories. The implications of understanding the scope of quarrying within a Talayotic site does affect aspects mentioned by these authors, such as relationships within a community and the way knowledge is transmitted amongst its members, but including both open and constructed areas might add more information needed to draw general conclusions. In other words, not only large monuments were being used to create a sense of social coherence or identity. Open spaces within the site had a function that could vary from being a quarry to organizing circulation patterns or social gatherings. In order to be able to elaborate on elites and social complexity within these Prehistoric monumental settlements we need more research regarding manpower, quarrying and building techniques, domestic spaces and settlement layouts, which would certainly give us the general picture of the Late Iron Age in the Balearic Islands.

All of the above shows the need for reinterpreting the urbanism of Iron Age Talayotic sites, the study of their open spaces, and the exploitation of raw materials. Many studies in the past (including Torre d'en Galmés) have focused on the archaeology inside the monumental buildings, excavating within the walls of structures, and studying the findings inside. The areas in between the buildings have not been greatly stud- 

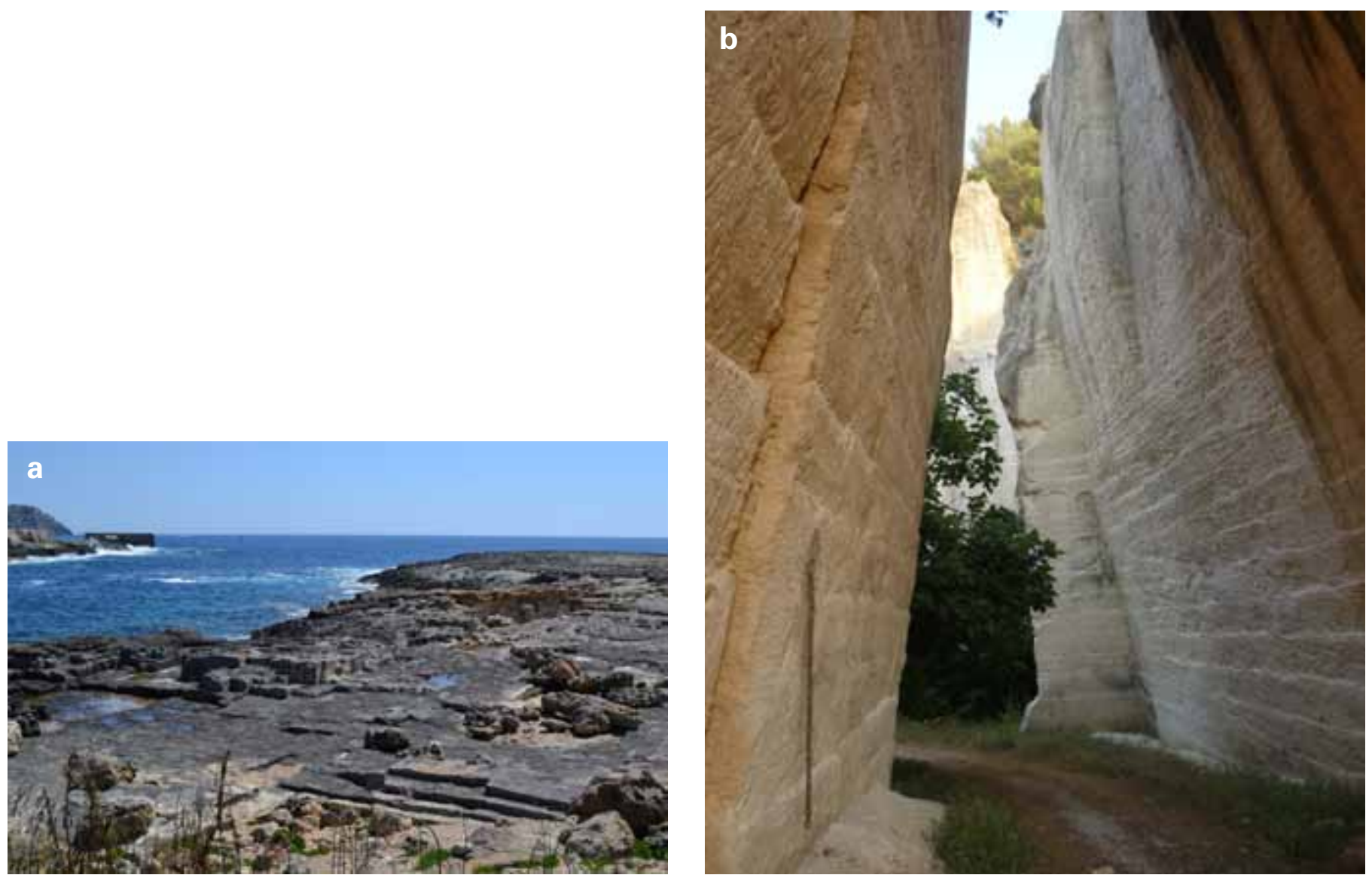

Figure 11. Two examples of modern limestone quarries in Menorca ranging from the $18^{\text {th }}$ to $20^{\text {th }}$ centuries. These operations exploited softer limestone, which was never used in prehistoric sites. Because of its softness and massiveness, these recent quarrying operations involved the cutting out of blocks with chisels and saws. These practices contrast with those at Talayotic sites, where natural joints and bedding planes in the limestone were exploited, some clearly cut by chisels to produce the building stones. (a) Modern quarry at Cala Sant Esteve, at the Harbour of Mahón, Menorca. (b) Recently abandoned limestone quarry about $3.3 \mathrm{~km} \mathrm{~N}$ of Torre d'en Galmés. Blocks here were removed by saws, made possible by the massive, soft marly aspect of this limestone, which represents an ancient Miocene lagoon. Scale is given by fig tree in the rear of the photo.

Figura 11. Dos ejemplos de canteras modernas de los siglos XVIII y XX. En este caso, la roca extraída consiste en calizas blandas -denominadas marés-, nunca utilizadas en construcciones talayóticas. (a) Cantera de la Cala Sant Esteve, en el puerto de Mahón, Menorca. (b) Cantera de Santa Ponça, cercanas a Torre d'en Galmés.

ied, and the open spaces have not been looked at carefully. This paper proves the richness of the site of Torre d'en Galmés and the potential for further research beyond the constructed structures.

\section{Acknowledgments}

We are indebted to Mercedes Planas and Martin Wilson for their mapping and surveying, and to all the students who participated in the BU field school over the years. We thank our colleagues Ricardo Elia and James Wiseman for being the co-directors of the field school for so many years and keeping the students' spirit up, and to our graduate students who super- vised field and laboratory work, especially Meredith Anderson Langlitz, Alexander Smith, Ilaria Patania, Jonathan Ruane, Marta Ostovich, and Kevin Mullen. We are grateful to our friends and colleagues in Menorca: Elena Sintes, Simón Gornés, and Joana Gual for engaging in discussion about the Talayotic culture. Finally, we thank BU Study Abroad and the Consell Insular de Menorca for financial support.

\section{References}

Bonanno, A., Gouder, T., Malone, C. and Stoddart, S. 1990. Monuments in an island society: the Maltese context. World Archaeology, 22 (2), 190-205. 
Pérez-Juez, A. y Goldberg, P., 2018. Evidence of Quarrying at the Iron Age Site of Torre... Boletín Geológico y Minero, 129 (1/2): $353-370$

Canti, M.G. 2003. Aspects of the chemical and microscopic characteristics of plant ashes found in archaeological soils. Catena, 54 (3), 339-361.

Courty, M.-A., Goldberg, P. and Macphail, R.I. 1989. Soils and Micromorphology in Archaeology. Cambridge University Press, Cambridge, 344 pp.

Dayton, C., 2002. Torre d'en Galmés 2002 GPR Preliminary report. Boston University Field School, Menorca, Unpublished.

Ferrer, A., Joan, G., Lara, C. and Pons, J. 2011. El jaciment de Torre d'en Galmés (Alaior, Menorca). Les intervencions d'Amics del Museu de Menorca: Cercle 7. In: Gual, J. (ed.), III Jornades d'Arqueologia de les IIles Balears, Consell Insular de Menorca, Mao, Menorca, 109.

Galván, V.A. and Ferrer, M.-J. 2000. Extracción de marés. Utillaje y procedimiento. In: Graciani, A., Huerta, S., Rabasa, E. and Tabales, M. (eds.), Actas del Tercer Congreso Nacional de Historia de la Construcción, CEHOPU, Sevilla, 336-340.

García-Amengual, E. 2012. El proceso constructivo de la Torre I del yacimiento del Puig de Sa Morisca. In: Riera, M. (ed.), IV Jornades d'Arqueoloogia de les Illes Balears, Eivissa, 53-59.

Goldberg, P. and Macphail, R. 2006. Practical andTheoretical Geoarchaeology. Blackwell Publishing, Oxford, 472 pp.

Gornés, J.S., Guerrero, V.M., Jordi Hernández-Gasch, Nicolás, J.C. and Strydonck, M.V. 2001. La campanya de excavación de 2001 en Biniparratx Petit (Menorca). Avance de los primeros anàlisis radiocarbónicos. Mayurqa, 27, 227-235.

Guerrero, V.M., Sanmartí, J., Hernández, J., Gornés, J.S., Gual, J., López, A. and Nicolás, J.C. 2002. Biniparratx Petit (Sant Lluís): a Research and Re-evaluation project in the Southeast of the Island of Minorca. In: Waldren, W. and Ensenyat, J. (eds.), World Islands in Prehistory, $V$ Deia International Conference of Prehistory. British Archaeological Reports, International Series, 502-516.

Hernández-Gasch, J. and Aramburu-Zabala Higuera, J. 2005. Murallas de la Edad del Hierro en la cultura talayótica. El recinto fortificado del poblado de Ses Païses (Artà, Majorca). Trabajos de prehistoria, 62 (2), 125-149.

Hunt, M.A., Llull, B., Perelló, L., Perelló, D. and Salvà, B. 2013. Sa Mitjalluna: minería prehistórica de cobre en Illa d'en Colom (Mahón, Menorca). De Re Metallica, 21, 45-57.

Juan, G., Pons, J. 2005. Talatí de Dalt 1997-2001. 5 anys d'investigació a un jaciment talaiòtic tipus de Menorca. Museu de Menorca, Menorca.

Kolb, M.J., 2005. The Genesis of Monuments Among the Mediterranean Islands, In: Blake, E. and Knapp, B. (Eds.), The Archaeology of Mediterranean Prehistory. Blackwell Publishing, Oxford, 156-179.

Kopper, J.S. and Rosselló-Bordoy, G. 1974. Megalithic quarrying techniques and limestone technology in Eastern Spain. Journal of Field Archaeology, 1, 161-170.
Menorca, 2015. Soil cover in Torre d'en Galmès area, Infrastructura de Dades Espacials (http://ide.cime.es/ visoride/), Consell Insular de Menorca, Mahon, Menorca.

Pérez-Juez, A., 2011. Excavaciones en la Casa 2 del yacimiento de Torre d'en Galmés, Alaior: propuestas para el hábitat talayótico. In: Gual, J. (ed.), III Jornadas d'Arqueologia de les Illes Balears. Consell Insular de Menorca, Mao, Menorca.

Pérez-Juez, A., 2011. Excavaciones en la Casa 2 del yacimiento de Torre d'en Galmés, Alaior: propuestas para el hábitat talayótico. In: Gual, J. (ed.), III Jornadas d'Arqueologia de les Illes Balears. Consell Insular de Menorca, Mao, Menorca, 119-129.

Pérez-Juez, A., Goldberg, P. and Cabanes, D. 2011. Estudio interdisciplinar del hábitat post-talayótico: bioarqueología, geoarqueología y registro arqueológico parala revisión metodológica de la arqueología en Menorca. ARQUEO MEDITERRÀNIA, 12, 139-149.

Pérez-Juez, A., 2013. Talayotic Culture. In: Bagnall, R.S., Brodersen, K., Champion, C.B., Erskine, A. and Huebner, S.R. (eds.), The Encyclopedia or Ancient History. Blackwell Publishing, Oxford, 6518-6520.

Renfrew, A.C., Todd, I. and Tringham, R. 1974. Beyond a Subsistence Economy: The Evolution of Social Organization in Prehistoric Europe. Bulletin of the American Schools of Oriental Research. Supplementary Studies, 20, 69-95.

Rosell, J., Gomez-Gras, D. and Elizaga, E. 1989. Cala en Brut, Alaior, Santandria y Cala en Porter. Mapa Geologico de Espana, E, 1 : 25000, 645b-646(1-2-4) 38.

Rosselló Bordoy, G., Plantalamor Massanet, L. and Soberats Liegey, F. 1984. Excavaciones arqueológicas en Torre d'en Gaumes (Alayor, Menorca) : El recinto de Taula y el sistema de recogida de aguas (Campañas 1974, 1975 y 1977). Ministerio de Cultura. Dirección General de Bellas Artes y Archivos. Subdirección de Arqueología y Etnografía, Madrid, 105-197

Rosselló Bordoy, G. 1986. El poblado prehistórico de Torre d'en Gaumes (Alaior). Institut d'Estudis Balèarics, Palma, Mallorca.

Serra, M.L. 1963. Canteras y pozos prehistóricos en Menorca. Ampurias, 25, 186-192.

Sintes, E. and Isbert, F. 2009. Investigación arqueológica y puesta en valor del Recinto Cartailhac. Una unidad doméstica del siglo II ANE en el poblado talayótico de Torre d'en Galmés. Patrimonio Cultural de España, 1, 251-259.

Soberats, F., Plantalamor, L. and Rosselló-Bordoy, G. 1984. Excavaciones arqueológicas en Torre d'en Gaumes (Alayor, Menorca): el recinto de Taula y el sistema de recogida de aguas (Campañas 1974, 1975 y 1977). Noticiario Arqueológico Hispánico, 19, 103-197.

TUTV. 2014. Menorca. http://www.tu.tv/videos/menorca-lapiedra-de-mares

Recibido: mayo 2015

Revisado: julio 2015

Aceptado: octubre 2015

Publicado: marzo 2018 